\title{
Feasibility study for the eradication of feral cats from Faure Island, Shark Bay, Western Australia
}

\author{
David Algar and Gary John Angus \\ Science Division, Department of Environment and Conservation, Wildlife Research Centre, \\ P.O. Box 51, Wanneroo, Western Australia 6946 Australia; E mail: dave.algar@dec.wa.gov.au
}

\begin{abstract}
Feral cats became established on Faure Island during the late $19^{\text {th }}$ century and were probably introduced from pearling vessels or by early pastoralists. The Australian Wildlife Conservancy (AWC), lease holders of the Faure Island pastoral lease, is planning to establish the area as a site for the conservation of threatened mammals. AWC proposes to translocate native mammal species to the island. To enable the successful recolonisation of the island by these species it would be necessary to implement a feral cat eradication program. This paper describes a preliminary feasibility study for the eradication of feral cats from the island.
\end{abstract}

Key words: felid, control, survey, poison baiting, distribution, abundance

\section{INTRODUCTION}

The Australian Wildlife Conservancy (AWC), responsible for the management of Faure Island, requested a preliminary feasibility study for the eradication of feral cats from the island in September 2000. The study was to enable reconnaissance of the island and provide information essential to commencing an eradication program in autumn 2001. Information such as bait acceptance, density and distribution of cats, vehicular access and the reliability of transport arrangements were essential in formulating a successful and efficient approach to cat control. As an eradication program was likely to employ a combination of control measures, including poison baiting and trapping, prior knowledge of the factors likely to affect efficacy were thought to be invaluable. Reconnaissance also provided an opportunity to optimise logistical arrangements (particularly transport), prior to engaging in an operational program when coordination of activities would be vital.

The study on Faure Island had the potential to clarify a range of issues affecting operational programs, particularly those at nearby Peron Peninsula in Shark Bay. Work at Peron by the Western Australian Department of Environment and Conservation (DEC) (Algar and Angus 2000; Algar et al. 2007) emphasised and quantified the importance of prey abundance on bait acceptance by feral cats. Faure Island offered the opportunity to directly compare baiting efficacy in the presence/ absence of key prey species. The two locations are just $18 \mathrm{~km}$ distant with almost identical geology, soil, vegetation and prevailing climatic conditions.
The key difference is the absence of Rabbits Oryctolagus cuniculus and the Spinifex Hoppingmouse Notomys alexis, on Faure Island. These two species are the principal prey items on Peron Peninsula ('Project Eden' unpub. data) and bait acceptance is clearly linked to rabbit abundance (Algar et al. 2007). This study further clarifies the situation, through comparison of concurrent bait uptake exercises at Peron Peninsula and Faure Island.

This paper documents the findings from the concurrent bait acceptance trials and details a proposal for a feral cat eradication program on Faure Island.

\section{METHODOLOGY}

\section{Study Site}

Faure Island, with an area of 5,816 ha, is located in Shark Bay at the head of the Hamelin Pool embayment, approximately $18 \mathrm{~km}$ east of Monkey Mia, Western Australia. The land systems on Faure are described by Payne et al. (1987) and Wilson (2008), and the vegetation is described by Beard (1976) and Keighery and Muir (2008).

Peron Peninsula, with an area of 105,000 ha, is located in Shark Bay immediately to the west of Faure Island. The peninsula is joined to the mainland by the narrow Taillefer Isthmus, and is the site of DEC's 'Project Eden', which is a component of the 'Western Shield' program to facilitate the recovery of Western Australian fauna species through broad scale predator baiting (Wyre 2004). 


\section{Baits and Bait Acceptance Trials}

\section{Bait}

The two bait acceptance trials outlined below were conducted using the standard feral cat bait (Trial 1) or the same bait injected with the biomarker Rhodamine B (Trial 2). The bait was approximately $20 \mathrm{~g}$ wet-weight, blanched and then dried to $15 \mathrm{~g}$. The bait was composed of $70 \%$ kangaroo meat mince, $20 \%$ chicken fat and $10 \%$ digest and flavour enhancers.

The Rhodamine B baits were injected with $50 \mathrm{mg}$ Rhodamine B per bait. Rhodamine B produces a bright pink stain in the gastro-intestinal tract immediately following bait consumption and subsequently produces markings in growing hair and whiskers. These markings are detectable as an orange fluorescence under filtered light (Fisher et al. 1999).

All baits were treated with the ant deterrent compound (Coopex®) at a concentration of $12.5 \mathrm{~g} \mathrm{~L}^{-1}$.

\section{Bait acceptance Trial 1}

A bait acceptance trial, using the standard sausage bait, was conducted on Faure Island on 20-22 September 2000. Coordination with DEC Denham District staff allowed the direct comparison of results from a concurrent exercise conducted at Peron Peninsula. Bait acceptance was assessed along a transect of $14.3 \mathrm{~km}$ (143 bait stations on Faure Island) and $20.0 \mathrm{~km}$ (200 bait stations on Peron Peninsula) over three consecutive nights. The limited suitable access available on Faure Island required that the same transect be used on consecutive nights, thus this was replicated on Peron Peninsula. Bait stations, comprising a single, non-toxic, sausage bait were placed every $100 \mathrm{~m}$ along the transects. Each bait station was swept to clear any sign of previous activity. Baits were distributed as close as possible to sunset. The bait uptake transects were examined the following morning, commencing one hour after dawn. Baits not removed were collected and fresh baits laid that night. Track assessment was conducted from a $4 \mathrm{WD}$ vehicle, driven at a speed of less than $10 \mathrm{~km} / \mathrm{h}$. Each bait station was inspected and the response of individual cats at the bait stations was recorded as:

- No track - there was no cat track within $3 \mathrm{~m}$ of the bait.

- Pass - a cat track was located within $3 \mathrm{~m}$ of the bait but the cat did not deviate from its path to inspect the bait.

- Visit - cat tracks were at least within $0.5 \mathrm{~m}$ of the bait and indicated that the animal had deviated from its path to inspect the bait, but had not eaten it.

- Uptake - bait removed. Cat prints approaching the bait, pes and/or tail imprints present, indicating the cat had assumed a sitting position. No non-target prints within reasonable reach of the bait position.

The spacing of baits on the transects often enabled individual cats to encounter more than one bait. The response of individual cats was recorded for each bait station; however, the highest ranking bait response for the individual animals was used in bait uptake summaries. Thus, if an individual cat was recorded as "passing" a bait and then later "visiting" another bait, the individual cat's bait response was categorized as a visit, and so on.

\section{Bait acceptance Trial 2}

The second bait acceptance trial was only conducted on Faure Island in conjunction with a trapping program, described below. Rhodamine B labelled baits were distributed at $100 \mathrm{~m}$ intervals along the entire trapping route. Rhodamine $B$ baits were laid on 19 September 2000 along tracks north of the first bait acceptance trial and on 22 September along the bait acceptance transect following completion of Trial 1. Bait acceptance was determined by the presence/absence of Rhodamine $B$ in the tissue/digestive tract of trapped cats.

As there have been consistently different returns from on-track and Rhodamine B assessment of bait uptake, the two methods were compared.

\section{Cat activity}

The location of individual cats along transects was recorded and their on-track distances logged. Feral cat use of vehicular tracks as a measure of activity was based upon the actual distances travelled on the track, rather than the total span of interaction with the track. The total on-track activity of all individuals present was recorded, including those that did not encounter baits.

Measuring exact on-track distances travelled by individuals is generally impractical. For the purposes of this exercise, the only objective measure of distance available to observers was the $100 \mathrm{~m}$ interval (initially measured with the vehicle odometer) at which baits were placed. Therefore recording of distance travelled was effectively coded for distances of $<100 \mathrm{~m}, \geq 100 \mathrm{~m}$ or multiples thereof. Distances of $<100 \mathrm{~m}$ were nominally coded as $10 \mathrm{~m}$, or multiples thereof.

The total on-track distance travelled was the sum of all $<100 \mathrm{~m}$ and $\geq 100 \mathrm{~m}$ intervals assigned to the particular individual.

\section{Non-target bait uptake}

Consumption of baits by non-target animals was recorded. Consumption was assigned to a particular non-target animal when no other animal was within reasonable reach of the bait position. 


\section{Trapping Program}

DEC researchers have developed a successful technique to trap feral cats. Each trap site consisted of a channel cleared into a bush to create a one-way (blind) trap set. Two Victor Soft-catch ( $\mathrm{N}^{\circ} 3$ ) leghold traps, one in front of the other were positioned at the entrance of the set. Cats were lured into the traps by the combination of an audio lure FAP (Feline Attracting Phonic) that produces the sound of a cat-call and a scent attractant 'pongo' (a blended mixture of cat faeces and urine).

Trap sites were located at approximately $1 \mathrm{~km}$ intervals immediately adjacent to the vehicle tracks. Their locations were recorded using a Garmin GPS 12XL. A total of 40 traps was set on 22 September, with four additional traps positioned the following day. A further six traps were located in the southern dune area on 24 September. Traps were left in position until 27 September. No traps were located in paddocks where stock was present.

\section{Necropsies}

Trapped cats were humanely destroyed using a 0.22 calibre rifle. All animals captured were sexed, weighed and a broad estimation of age (kitten, juvenile or adult) was recorded according to their weight. The weight/age classes for females were 0 $0.5 \mathrm{~kg}$ for kittens, $0.6-2.4 \mathrm{~kg}$ for juveniles and $2.5+$ $\mathrm{kg}$ for adults; males were $0-0.5 \mathrm{~kg}$ for kittens, $0.6-$ $2.9 \mathrm{~kg}$ for juveniles and $3.0+\mathrm{kg}$ for adults.

The pregnancy status and litter size of females was recorded by examining the uterine tissue for the presence of foetuses or placental scarring from the previous litter. Average litter size of trapped females provided an indication of the innate ability of the population to respond to control measures.

Stomach contents were examined to provide information on principal prey species. Knowledge of the key prey species is fundamental to determining the broad optimum time for toxic baiting. Seasonal trends in bait acceptance by feral cats are closely linked to trends in prey availability (Algar et al. 2007). Baiting is likely to be most effiective when key prey species are seasonally less abundant.

The gastro-intestinal tract was examined and whiskers collected to determine whether the cats had consumed a non-toxic biomarked bait.

\section{Cat density and distribution}

The trapping program in conjunction with assessment of track activity also provided a simple and effective method to assess cat abundance (Algar et al. 1999). In addition to this information, records of cat activity along the bait acceptance transect and evidence of cat activity in areas distant from the trapping route (principally along the coastal dunes) were used to provide an indication of the relative density and distribution of feral cats on Faure Island.

\section{RESULTS}

\section{Bait Acceptance Trials}

\section{Bait acceptance Trial 1}

Fifty percent of cats that came into contact with a bait laid on Faure Island during Bait Acceptance Trial 1 consumed at least one bait (Table 1). In the majority of instances however, multiple baits were taken by individual cats. When each cat present was considered individually over the three-day period, four individuals consumed baits on Faure Island. No cat consumed a bait on Peron Peninsula, despite the presence of cats along the transect (Table 1).

Table 1 Bait responses recorded during Bait Acceptance Trial 1 (standard bait).

\begin{tabular}{lccccc}
\hline $\begin{array}{l}\text { Site and } \\
\text { date }\end{array}$ & $\begin{array}{c}\text { No. cats } \\
\text { per } \\
\text { transect }\end{array}$ & $\begin{array}{c}\text { No. cats } \\
\text { contacting } \\
\text { baits }\end{array}$ & $\begin{array}{c}\text { Bait } \\
\text { pass }\end{array}$ & $\begin{array}{c}\text { Bait } \\
\text { visit }\end{array}$ & $\begin{array}{c}\text { Bait } \\
\text { uptake }\end{array}$ \\
\hline $\begin{array}{l}\text { Faure Island } \\
\text { 20/09/00 }\end{array}$ & 8 & 3 & 0 & 3 & 0 \\
21/09/00 & 6 & 4 & 1 & 0 & 3 \\
22/09/00 & 6 & 5 & 2 & 0 & 3 \\
Peron Peninsula & & & & \\
20/09/00 & 9 & 9 & 7 & 2 & 0 \\
21/09/00 & 9 & 9 & 7 & 2 & 0 \\
22/09/00 & 5 & 5 & 4 & 1 & 0 \\
\hline
\end{tabular}

\section{Bait acceptance Trial 2}

Analysis of the presence/absence of Rhodamine B in the trapped population indicated that three of the six animals captured had consumed at least one bait. One cat trapped on the beach was distant from any bait placement and bait locations may have been outside her home range. During the course of the trapping program it was noted that baits were still being taken by cats, six and seven days after baiting.

\section{Cat activity}

The distances travelled on-track by cats during Bait Acceptance Trial 1 on Faure Island was generally lower and more variable than on Peron Peninsula (Table 2). Vehicle tracks on Faure Island

Table 2 Distances ( $\mathrm{m}$ ) travelled on-track by cats during bait acceptance trials.

\begin{tabular}{lccc}
\hline Site and date & $\begin{array}{c}\text { No. cats } \\
\text { per transect }\end{array}$ & $\begin{array}{c}\text { Mean } \\
\text { distance }\end{array}$ & $\begin{array}{c}\text { Standard } \\
\text { error }\end{array}$ \\
\hline Faure Island & & & \\
20/09/00 & 8 & 127.5 & 99.5 \\
$21 / 09 / 00$ & 6 & 121.7 & 83.3 \\
22/09/00 & 6 & 201.7 & 183.7 \\
All days & 20 & 148.0 & 68.8 \\
Peron Peninsula & & & \\
20/09/00 & 9 & 126.7 & 31.7 \\
21/09/00 & 9 & 233.3 & 90.9 \\
22/09/00 & 5 & 12 & 2 \\
All days & 23 & 143.5 & 40.5 \\
\hline
\end{tabular}


Table 3 Percentage of baits removed by non-target species.

\begin{tabular}{|c|c|c|c|c|c|c|}
\hline $\begin{array}{l}\text { Site and } \\
\text { date }\end{array}$ & $\begin{array}{c}\text { Spinifex } \\
\text { hopping-mouse } \\
\text { (Notomys alexis) }\end{array}$ & $\begin{array}{l}\text { Sand Goanna } \\
\text { (Varanus } \\
\text { gouldii) }\end{array}$ & $\begin{array}{c}\text { Crow } \\
\text { (Corvus } \\
\text { bennetti) }\end{array}$ & $\begin{array}{c}\text { Emu } \\
\text { (Dromaius } \\
\text { novaehollandiae) }\end{array}$ & $\begin{array}{l}\text { Bustard } \\
\text { (Ardeotis } \\
\text { australis) }\end{array}$ & Total \\
\hline \multicolumn{7}{|c|}{ Faure Island } \\
\hline $20 / 09 / 00$ & - & 0 & 3.5 & 0 & 0 & 3.5 \\
\hline $21 / 09 / 00$ & - & 0 & 2.8 & 0 & 1 & 3.8 \\
\hline $22 / 09 / 00$ & - & 0 & 4.2 & 0 & 0 & 4.2 \\
\hline \multicolumn{7}{|c|}{ Peron Peninsula } \\
\hline $20 / 09 / 00$ & 3 & 0 & 18 & 0.5 & 0 & 21.5 \\
\hline $21 / 09 / 00$ & 2 & 0.5 & 45 & 0 & 0 & 47.5 \\
\hline $22 / 09 / 00$ & 3 & 0.5 & 38 & 8.5 & 0 & 50.0 \\
\hline
\end{tabular}

generally comprised two wheel ruts compared with the cleared tracks on Peron Peninsula.

\section{Non-target bait uptake}

Bait removal by non-target species was lower on Faure Island than on Peron Peninsula (Table 3), leaving a greater number of baits potentially available to cats over a longer time period. Population densities of non-target species that will consume cat baits appeared to be much lower on Faure Island than Peron Peninsula.

\section{Trapping Program}

Fifty leg-hold trap sets were located along the trapping route over the five-day trapping period, providing a total of 236 trap nights.

\section{Necropsies}

Six cats were trapped ( 3 males and 3 females; Table 4). Of the trapped female cats, only one was pregnant, the other two had placental scars from previous pregnancies. The average litter size (mean \pm s.e.) was $2.33 \pm 0.33$ kittens.

Table 4 Capture locations and records of trapped cats $\left({ }^{*} \mathrm{k}=\right.$ kitten, $\mathrm{j}=$ juvenile, $\mathrm{a}=$ adult $)$.

\begin{tabular}{|c|c|c|c|c|c|c|}
\hline Date & $\begin{array}{c}\text { Sample } \\
\text { No. }\end{array}$ & $\begin{array}{l}\text { Trap } \\
\text { No. }\end{array}$ & Sex & $\begin{array}{c}\text { Weight } \\
\text { (kg) }\end{array}$ & $\begin{array}{l}\text { Coat } \\
\text { colour }\end{array}$ & $\begin{array}{r}\text { Age } \\
(\mathbf{k} / \mathrm{j} / \mathbf{a})^{*}\end{array}$ \\
\hline $23 / 09 / 00$ & FI.01 & 01 & Male & 4.00 & Black & a \\
\hline $23 / 09 / 00$ & FI.02 & 15 & Female & $\begin{array}{r}3.00 \\
a\end{array}$ & $\begin{array}{l}\text { Black } \\
\text { and white }\end{array}$ & a \\
\hline $23 / 09 / 00$ & FI.03 & 20 & Female & 3.75 & Black & a \\
\hline $24 / 09 / 00$ & FI.04 & 39 & Male & 4.00 & Black & a \\
\hline $24 / 09 / 00$ & FI.05 & 20 & Male & 3.90 & $\begin{array}{c}\text { Black } \\
\text { and white }\end{array}$ & $\mathrm{a}$ \\
\hline $27 / 09 / 00$ & FI.06 & $\begin{array}{l}\text { Trap } 1 \\
\text { (beach) }\end{array}$ & Female & 3.50 & Black & $\mathrm{a}$ \\
\hline
\end{tabular}

The sand monitor (Varanus gouldii) was the dominant prey item in the stomach of the trapped cats, followed by skinks, small mammals (probably the house mouse Mus musculus; Schmitz and Richards, 2008), invertebrates and a bird (Table 5).
Table 5 Stomach volume and contents of captured cats.

\begin{tabular}{|c|c|c|}
\hline $\begin{array}{l}\text { Sample } \\
\text { No. }\end{array}$ & $\begin{array}{l}\text { Approximate } \\
\text { stomach } \\
\text { volume }(\%)\end{array}$ & Stomach contents \\
\hline FI.01 & 25 & Varanus gouldii \\
\hline FI.02 & 25 & $\begin{array}{l}V . \text { gouldii, Ctenotus sp., } \\
\text { Eremiascincus sp., } \\
\text { grasshopper }\end{array}$ \\
\hline FI.03 & 25 & $\begin{array}{l}V . \text { gouldii, skink, Mus } \\
\text { musculus, bird, grasshopper }\end{array}$ \\
\hline FI.04 & 25 & $\begin{array}{l}V \cdot \text { gouldii, Simoselaps } \\
\text { littoralis }\end{array}$ \\
\hline FI.05 & Trace & $V$. gouldii, $M$. musculus \\
\hline FI.06 & 0 & - \\
\hline
\end{tabular}

\section{Cat Density}

The location of cat activity along the bait acceptance transect, trapping route and evidence of cat activity located during the intensive ground searches indicated a population density of approximately 40 cats on Faure Island.

\section{DISCUSSION AND RECOMMENDATIONS FOR A CAT ERADICATION CAMPAIGN ON FAURE ISLAND}

This feasibility study for cat control on Faure Island has indicated that eradication is possible. Reconnaissance of the island and the program conducted has provided the information essential to the development of a proposal for an eradication campaign.

Baits were readily consumed by cats on Faure Island in comparison with the lack of bait acceptance by cats on Peron Peninsula. This difference in bait consumption between the two areas is likely due to the presence of an abundant key prey population (rabbits and spinifex hoppingmouse) on Peron Peninsula and their absence on Faure Island. On Faure Island during the period of this study, the principal dietary item was reptiles; in particular young Varanus gouldii. Baits were deployed on Faure Island when activity of varanids and their size provided a reasonable prey source for cats, yet bait uptake was still high. Bait consumption generally increases through summer 
into autumn as prey availability declines (Algar et al. 2007). On Faure Island, growth of varanids is likely to reduce their vulnerability to predation and bait consumption by cats may increase further. Alternatively, larger varanids may consume more baits, reducing their availability to cats. Baiting programs conducted during autumn are unlikely to be affected by rainfall.

As a result of the high bait uptake, it is proposed that an aerial baiting campaign be adopted as the primary control technique for feral cats. Following the baiting campaign an intensive trapping program will be employed to remove any cats that remain. This control strategy was successfully employed on the Montebellos (Algar and Burbidge 2000; Algar et al. 2002).

\section{Aerial Baiting Campaign}

To maximise baiting efficacy a baiting intensity of $100 \mathrm{baits} / \mathrm{km}^{2}$ is proposed. This baiting intensity is ten times that used on-track (this study) and will optimise bait availability and the likelihood of cats encountering a bait when hungry. It is suggested that the aerial baiting program be conducted such that one flight line follows the coast, another deploys baits in the interdunal swales and the remaining flight transects are at $1 \mathrm{~km}$ intervals across the island. The toxin '1080' (sodium monofluoroacetate) will be injected into the baits at a dose rate of $4.5 \mathrm{mg} / \mathrm{bait}$. There are no non-target species on the island potentially at risk from this baiting regime. Results from this feasibility study have indicated that there are approximately 40 adult cats present on the island. Reduction of this figure will be used as a measure of baiting efficacy.

\section{Trapping and Monitoring Program}

An intensive trapping and cat activity monitoring program across the island will commence ten days after baiting. The ten day period will allow the cats sufficient time to encounter and consume baits prior to bait degradation. Initially, traps will be located at $500 \mathrm{~m}$ intervals along all tracks, around the birridas and along the coast/dunes to provide extensive coverage of the island. Cat activity will be monitored en route to identify the number of cats remaining following baiting and targeting specific individuals. Ground baiting may also be used to target individual cats. The trapping and monitoring program will require four personnel for a period of 30 days. The complete eradication of cats from Faure Island will be required before the reintroduction of threatened mammal species can commence.

\section{ACKNOWLEDGEMENTS}

We gratefully acknowledge AWC for providing the funds to conduct this preliminary feasibility study for the eradication of feral cats on the island.
Thanks are extended to Barry Wilson (formerly of $\mathrm{AWC}$ ) for requesting and organising the study. Special thanks go to Dick Hoult whose knowledge of the island proved invaluable, for transporting the equipment to and from the island and his sense of humour while manhandling the gear. The authors also wish to acknowledge Jacqui Richards (AWC) for her comments on the paper.

The techniques used in this program have been approved by the Department of Environment and Conservation's Animal Ethics Committee.

\section{REFERENCES}

Algar, D., Angus, G.J. and Sinagra, J.A. (1999). Preliminary assessment of a trapping technique to measure feral cat abundance. Project ISP\#11, Report to Environment Australia. Department of Conservation and Land Management, Western Australia.

Algar, D. and Angus, G.J. (2000). Recommendations on a control strategy for feral cats at Peron Peninsula, Western Australia. Report to the Project Eden Management Committee. Department of Conservation and Land Management, Western Australia.

Algar, D. and Burbidge, A.A. (2000). Isle of cats: the scourging of Hermite Island. Landscope 15: 18-22.

Algar, D., Burbidge, A.A. and Angus, G.J. (2002). Cat Eradication on the Montebello Islands (pp. 14-18). In: Veitch, C. R. and Clout, M. N. (eds), Turning the Tide: the eradication of invasive species. Invasive Species Specialist Group of the World Conservation Union (IUCN), Auckland, New Zealand.

Algar, D., Angus, G.J., Williams, M.R. and Mellican, A.E (2007). Influence of bait type, weather and prey abundance on bait uptake by feral cats (Felis catus) on Peron Peninsula, Western Australia. Conservation Science, Western Australia 6: 109-149.

Beard, J. S. (1976). The natural regions of the deserts of Western Australia. Journal of Ecology 5: 677-711.

Fisher, P., Algar, D. and Sinagra, J.A. (1999). Use of Rhodamine $B$ as a systemic bait marker for feral cats (Felis catus). Wildlife Research 26: 281-85.

Keighery, G. and Muir, W. (2008). Vegetation and vascular flora of Faure Island, Shark Bay, Western Australia. Records of the Western Australian Museum Supplement 75: 11-19.

Payne, A.L., Curry, P.J. and Spencer, G.F. (1987). An inventory and condition survey of rangelands in the Carnarvon Basin, Western Australia. Technical Bulletin No. 73. Western Australian Department of Agriculture.

Schmitz, A. and Richards, J.D. (2008). A survey of the terrestrial vertebrates of Faure Island, Shark Bay, Western Australia. Records of the Western Australian Museum Supplement 75: 33-37.

Wilson, B. (2008). Background information on Faure Island. Records of the Western Australian Museum Supplement 75: 1-9.

Wyre, G. (2004). Management of the Western Shield program: Western Shield review - February 2003. Conservation Science Western Australia 5: 20-30. 


\section{Guide to Authors}

\section{Records of the Western Australian Museum}

\section{Subject Matter}

Original research, reviews and observations in all branches of natural science and human studies will be considered for publication. However, emphasis is placed on studies pertaining to Western Australia and neighboring regions. Longer papers will be considered for publication as Supplements to the Records of the Western Australian Museum. Such publications may attract charges to the authors to offset the costs of printing - authors should consult the editors before submitting large manuscripts. Short communications should not normally exceed three typed pages and this category of paper is intended to accommodate observations, results or new records of significance. All material must be original and not have been published elsewhere.

\section{Presentation}

Authors are advised to follow the layout and style in the most recent issue of the Records of the Western Australian Museum including headings, tables, illustrations and references. When in doubt, use a simple format that is easily edited. Please provide line numbers throughout the MS (e.g., in Word go to File Page Setup Layout (tab) Line Numbers (button), add line numbers and click on "continuous" numbering).

The title should be concise, informative and contain key words necessary for retrieval by modern searching techniques. An abridged title (not exceeding 50 character spaces) should be included for use as a running head.

An abstract must be given in full length papers but not short communications, summarizing the scope of the work and principal findings. It should normally not exceed $2 \%$ of the paper and be suitable for reprinting in reference periodicals. At the end of the abstract, provide several keywords not already included in the title.

The International System of units should be used. Spelling should follow the Concise Oxford Dictionary. Numbers should be spelled out from one to nine in descriptive text; figures used for 10 or more. For associated groups, figures should be used consistently (e.g., "5 to 10 ", not "five to 10 ").

Systematic papers must conform with the International Codes of Botanical and Zoological Nomenclature and, as far as possible, with their recommendations.

Synonymies should be given in the short form (taxon, author, date, page) and the full reference cited at the end of the paper. All citations, including those associated with scientific names in taxonomic works, must be included in the references.

\section{Manuscripts}

Manuscripts should be submitted electronically as PDF's or Word files to the editors (listed below). For manuscripts with large image files, submission of a CD is acceptable. Manuscripts must be 1.5 or double-spaced throughout and margins at least $25 \mathrm{~mm}$ wide. On separate pages include tables (plus headings) and figure legends. Tables should be numbered consecutively, have headings which make them understandable without reference to the text, spell out generic names and be referred to in the text.

\section{Figures}

Lower resolution images can be inserted into a PDF or Word document for review. Upon acceptance, high resolution (6$10 \mathrm{Mb}$ ) images in TIFF or JPEG format can be e-mailed or burned to $\mathrm{CD}$ and posted to the editors. We prefer TIFF files for figures. For Adobe Illustrator and Sigmaplot, save in .eps (encapsulated postscript) format; for PowerPoint, save in .wmf (windows metafile format); for Excel, save as Excel 97 worksheet (must contain spreadsheet and embedded chart); and for CorelDraw, save as an .eps file that may be opened by Adobe Illustrator.

Scanned photographs should be saved as TIFF files. All TIFF files should be compatible with Adobe Photoshop. If figures are prepared in a paint program, for black-and-white line art save at 600 dpi as a black-and-white bitmap (not greyscale or colour), and greyscale and colour line art at $300 \mathrm{dpi}$.

Scale must be indicated on illustrations. Use arrows or other aids to indicate specific features mentioned in the text. All maps, line drawings, photographs and graphs should be numbered in sequence and referred to as "Figure" (no abbreviation) in the text and captions. Each figure should have a brief, fully explanatory caption.

\section{References}

In the body of the text, references should be cited as follows:

McKenzie and colleagues (McKenzie 1999, 2000; McKenzie et al. 2000) found that bat frequencies were highest on full moons, contra previous workers (Smith and Jones 1982; Berman 1988; Zucker et al. 1992).

All references must be cited in the text by author and date and all must be listed alphabetically at the end of the paper. The names of journals are to be given in full. Consult a recent edition of the Records for style. For taxonomic papers, include full references for all taxonomic groups mentioned in the text. In manuscripts dealing with historical subjects references may be cited as footnotes.

\section{Processing}

All manuscripts are reviewed by at least two referees whose reports assist the editors in making their decision whether to accept the paper. The review process usually takes from one to three months, although the review process and typesetting for longer manuscripts and supplements are usually longer.

The senior author is sent one set of page proofs electronically which must be returned within one week after receipt.

The senior author will receive 25 free reprints, a PDF and a copy of the entire issue. Additional offprints can be ordered at page proof stage.

\section{Editors}

Manuscripts can be submitted to either Mark Harvey (mark.harvey@museum.wa.gov.au; invertebrate animals) or Paul Doughty (paul.doughty@museum.wa.gov.au; human studies [anthropology, archaeology or history] and vertebrate
animals). 